\title{
вмJ Global Health COVID-19 raises a health and human rights imperative to advance a UN Convention on the Rights of Older Persons
}

\author{
Benjamin Mason Meier $\left(\mathbb{0},{ }^{1}\right.$ Victoria Matus, ${ }^{2}$ Maximillian Seunik ${ }^{3}$
}

\begin{abstract}
To cite: Meier BM, Matus V, Seunik M. COVID-19 raises a health and human rights imperative to advance a UN Convention on the Rights of Older Persons. BMJ Global Health 2021;6:e007710. doi:10.1136/ bmjgh-2021-007710
\end{abstract}

Handling editor Seye Abimbola

Received 13 October 2021 Accepted 9 November 2021

Check for updates

(C) Author(s) (or their employer(s)) 2021. Re-use permitted under CC BY-NC. No commercial re-use. See rights and permissions. Published by BMJ.

${ }^{1}$ University of North Carolina at Chapel Hill, Gillings School of Global Public Health, Chapel Hill, North Carolina, USA

${ }^{2}$ Pan American Health Organization, Washington, District of Columbia, USA

${ }^{3}$ Young Diplomats of Canada, Toronto, Ontario, Canada

Correspondence to Professor Benjamin Mason Meier; bmeier@unc.edu

\section{ABSTRACT}

The COVID-19 pandemic has revealed the inequitable health harms and human rights violations faced by older persons, raising a need to support healthy ageing policy as a human rights imperative. However, international human rights law has long neglected the health-related human rights of older persons. Drawing from evolving advocacy efforts to advance the rights of older persons through the United Nations (UN), tentative initial steps have been taken at the regional level, with states in the Americas codifying intersectional rights obligations underlying health through the Inter-American Convention on Protecting the Human Rights of Older Persons. These international and regional efforts provide a foundation to advance the right to health for older persons. Amid an ongoing demographic transition and an inequitable pandemic response, the prospective UN Convention on the Rights of Older Persons provides a crucial opportunity to elaborate and uphold the international legal obligations necessary to facilitate healthy ageing.

Every life matters. Every life is precious, no matter their age. We cannot allow the narrative that some lives are worth saving and others are not.

- Tedros Adhanom Ghebreyesus (2020)

The health burden faced by older persons in the COVID-19 pandemic-compounded by government neglect of this inequitable plight-belies the fundamental notion that all people are equal in dignity and rights. There is an urgent need to secure the human rights of older persons, with a proposed international treaty uniquely poised to advance these rights underlying healthy ageing and address intersectional health and human rights concerns. This analysis examines the evolution of health-related human rights of older persons under international law, providing a foundation through the United Nations (UN) to realise healthy ageing under
Summary box

- Governments have forsaken the lives of older persons in the COVID-19 pandemic, exposing the extent to which ageist discrimination permeates health policymaking and undermining the notion that all people are equal in dignity and rights.

- Although human rights have evolved under international law to support the health of older persons, the ongoing demographic transition and inequitable pandemic response have raised an imperative for new international legal obligations.

- In the absence of an international treaty, states in the Americas have come together to develop a regional treaty, the 2017 Inter-American Convention on Protecting the Human Rights of Older Persons, recognising intersectional threats to the health-related human rights of older persons.

- These international and regional efforts provide a foundation for the development of a new international treaty, with advocates looking to the United Nations (UN) to develop a Convention on the Rights of Older Persons.

- This prospective UN convention provides a crucial opportunity to elaborate comprehensively the health and human rights of older persons, creating specific international obligations and accountability mechanisms to realise the right to health, prevent discrimination and facilitate healthy ageing.

a proposed Convention on the Rights of Older Persons.

\section{COVID-19 UNDERMINES THE HEALTH \& HUMAN RIGHTS OF OLDER PERSONS}

The longstanding neglect of the health and human rights of older persons has been thrown into sharp relief by the COVID-19 pandemic. ${ }^{1}$ Reversing recent gains in longevity, the world has confronted an unprecedented loss of elders in the pandemic, with case-fatality rates rising with both age and the presence of underlying immunological, cardiovascular 
and respiratory conditions common in older age. ${ }^{2}$ Emerging data reveal that the risk of hospitalisation and death from COVID-19 increases rapidly with chronological age. In many countries, a disproportionate share of deaths related to COVID-19 has been linked to long-term care facilities, which have offered inadequate disease prevention and treatment to older persons. ${ }^{3}$ Given the systemic underfunding of nursing care and devaluation of care work (largely performed by poorly paid and trained health workers, as well as family members with competing responsibilities), these besieged care settings have neglected to provide safe environments and quality care to residents.

While the pandemic has threatened the lives of older persons, it has also exposed the extent to which ageist discrimination permeates health policy decision-making. In the UK, Prime Minister Boris Johnson is alleged to have avoided early public health measures because he saw the risk to be faced predominantly by older persons. ${ }^{4}$ Similar sentiments have been echoed by leaders of other high-income, middle-income and low-income countries reflecting the global challenge of ageism. Brazilian President Jair Bolsonaro abdicated government responsibility for protecting older persons, suggesting that 'each family has to protect its elderly, not throw that on the State' and arguing that quarantine measures should apply only to older persons to limit impacts on the Brazilian economy. ${ }^{5}$ From India to the Philippines, vaccination campaigns have prioritised 'working-aged' adults, leading some to conclude that this preventable death constitutes 'statesanctioned gerontocide'. ${ }^{6}$ Throughout the world, the implicit shared calculus among political leaders is that the perceived physical frailty and limited economic productivity of older persons render them less worthy of safeguarding.

As a result of this entrenched prejudice, chronological age has been employed in the pandemic response to allocate scarce resources, including ventilators and intensive care units, limiting the accessibility of healthcare and underlying determinants of health. Categorising all older persons in a single, undifferentiated risk group, clinical ethics guidelines often recommend the use of chronological age as a criterion for rationing life-saving care, denying age-appropriate care and leading to disproportionate death. ${ }^{7}$ Lockdowns and restrictions in the pandemic have exacerbated loneliness for older persons, with social isolation increasingly understood to pose a risk of premature death from all causes - with additional risks to mental health from dementia, depression and anxiety. ${ }^{8}$ In failing to account for the diverse capacities and age-appropriate needs of older populations, states have undermined the inherent dignity and infringed the human rights of older persons.

This inequitable plight in the pandemic reveals the neglect of older persons under international human rights frameworks. Where advancements of the human right to health have largely omitted the healthrelated needs of older persons-especially those facing intersectional challenges-the UN has sought to redress this neglect in the pandemic response. In a joint statement, leaders of the UN, WHO and Office of the UN High Commissioner for Human Rights (OHCHR) affirmed that 'no person, young or older, is expendable', calling for 'a surge in global and national solidarity' to support the rights of older persons. ${ }^{9}$ Providing human rights support to states, OHCHR issued COVID-19 guidance to affirm that 'older persons have the same rights as any other age group', raising attention to the specific risks faced by older persons and insisting that medical decisions be based on individual clinical assessments rather than chronological age. ${ }^{10}$ These actions in the COVID-19 response have galvanised efforts to safeguard the health and human rights of our elders, recognising health-related rights under international law.

\section{PROMOTING HEALTH-RELATED RIGHTS UNDER INTERNATIONAL LAW}

With rising threats to dignity and rights, human rights have evolved under international law to support the health of older persons. Since the origins of international human rights law under the UN, with states first proposing a 'declaration of old age rights' as early as $1948,{ }^{11}$ international instruments have long been proposed to realise the rights of older persons. Yet, while the 1948 Universal Declaration of Human Rights recognised a right to health and 'security...in the event of old age', ${ }^{12}$ subsequent codifications of international human rights law were slow to adopt explicit protections of the health-related rights of older persons, with prohibitions of discrimination often excluding discrimination on the basis of age. Seeking to advance these rights at the regional level, states in the Americas have come together to develop a regional treaty, the 2017 Inter-American Convention on Protecting the Human Rights of Older Persons. These international and regional efforts, as seen in figure 1, provide a foundation for the development of a new international treaty.

\section{UN EFFORTS}

Longstanding advocacy from non-governmental organisations spurred global action to establish human rights under international law to promote the health of older persons. To provide human rights protections for the specific needs of ageing populations, non-governmental advocates at the 1982 World Assembly on Ageing pressed states to adopt the Vienna International Plan of Action on Ageing, recommending policies to realise primary healthcare and emphasising a multisectoral approach that looks 'beyond disease orientation' to ensure 'total well-being'. ${ }^{13}$ This plan of action became the basis for the 1991 UN Principles for Older Persons, outlining 18 principles under five rights-based themes: independence, participation, care, self-fulfilment and dignity. ${ }^{14}$ These UN principles provided a framework for health-related obligations under international human rights law, with 
International Efforts

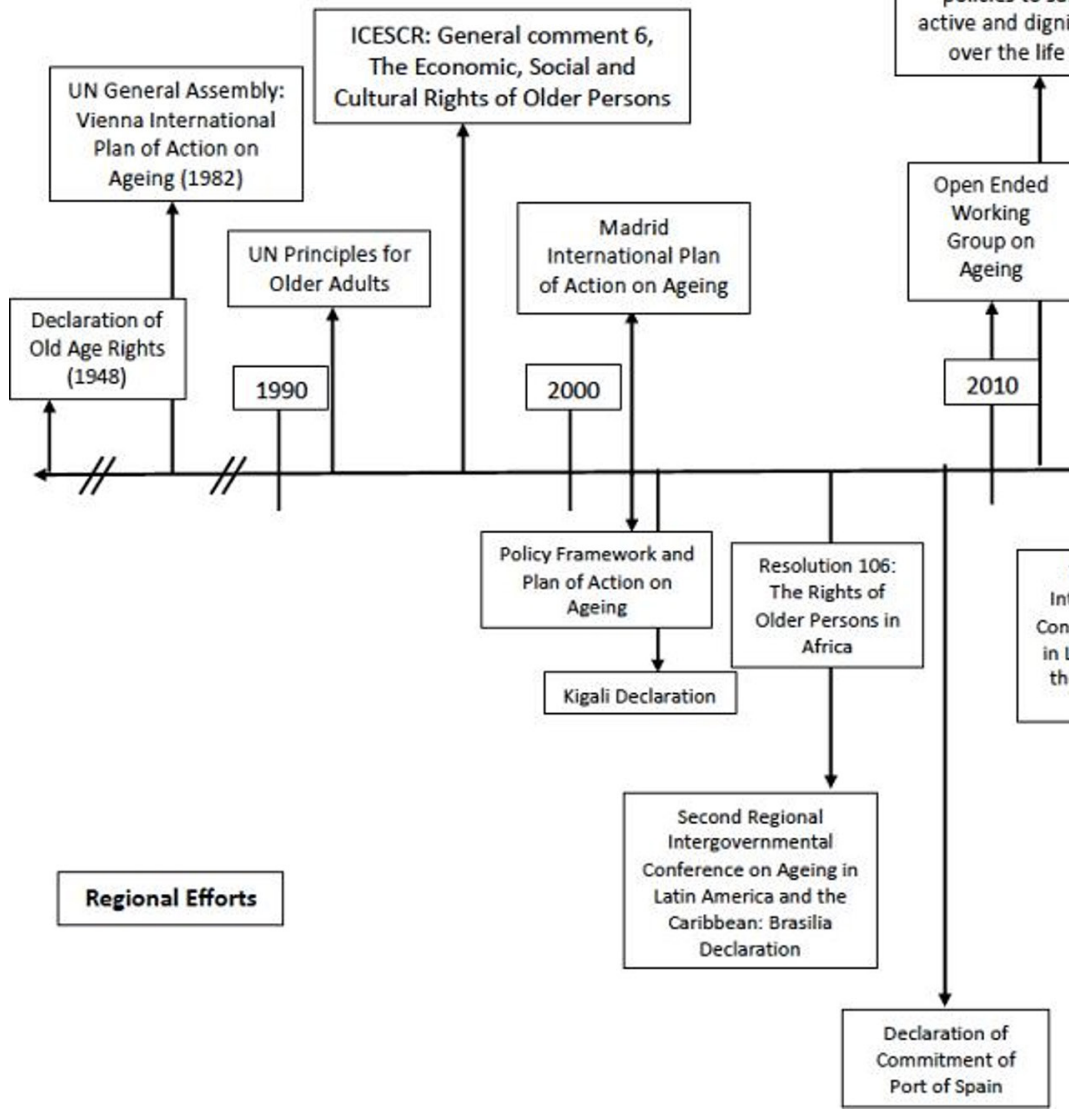

UN Special Rapporteur

report on the need for

policies to safeguard

ve and dignified aging

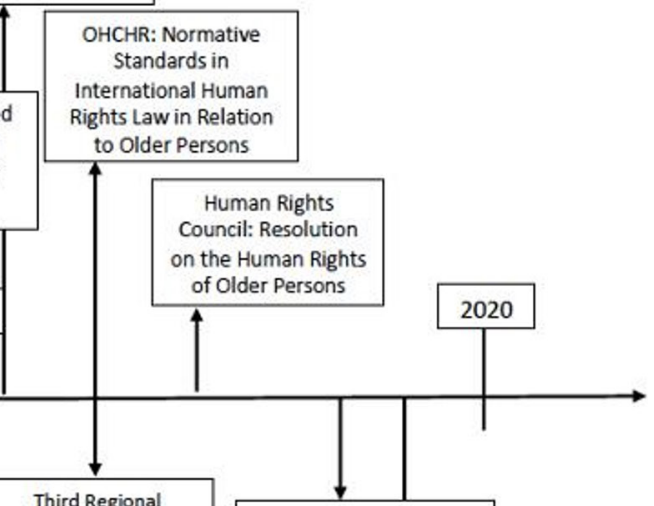

tergovernmenta

Conference on Ageing

the Caribbean: San José Charter
Protocol to the African

Charter on Human and

People's Rights on the

Rights of Older Persons

Figure 1 International and regional developments to advance the health-related rights of older persons. ICESCR, International Covenant on Economic, Social and Cultural Rights; OAS, Organization of American States; OHCHR, Office of the United Nations High Commissioner for Human Rights; UN, United Nations.

the UN Committee on Economic, Social and Cultural Rights adopting a 1995 General Comment on the rights of older persons, specifying obligations 'to preserve the health of the elderly and take a comprehensive view, ranging from prevention and rehabilitation to the care of the terminally ill'. ${ }^{15}$ With states ready to recognise obligations to progressively realise the right to health in light of the unique challenges faced by older persons, the Second World Assembly on Ageing adopted the 2002 Madrid International Plan of Action on Ageing (MIPAA) 'to ensure that persons everywhere are able to age with security and dignity and to continue to participate in their societies as citizens with full rights'. ${ }^{16}$

In seeking to strengthen obligations to uphold the rights of older persons, the UN General Assembly in 2010 established an Open-Ended Working Group on Ageing (OEWGA) - bringing together national, international and non-governmental representatives to examine gaps in international frameworks. The OEWGA concluded that a new international convention on the human rights of older persons 'would complement the existing regional mechanisms and instruments, in addition to protect and dignify older persons'. ${ }^{17}$ Drawing from these efforts to advance the health-related rights of older persons, the UN Special Rapporteur on the right to health developed a 2011 report on the need for policies to safeguard active and dignified ageing over the life course, highlighting the specific rights and freedoms applicable to older populations (including informed consent, autonomy and guardianship) and recognising limitations of international law in addressing the right to health for older persons. ${ }^{18}$ To redress these limitations, the UN General Assembly in 2012 formally requested that the OEWGA study the necessary provisions that should be included in an international legal instrument to promote the rights and dignity of older persons. ${ }^{19}$

The UN human rights system has sought to develop principles to frame such an international treaty, with OHCHR drawing from the MIPAA in 2012 to issue 'Normative Standards in International Human Rights Law in Relation to Older Persons', examining how existing human rights instruments had already created implicit obligations to protect the right to health of older persons. ${ }^{20}$ Advancing more explicit obligations, the UN Human Rights Council adopted a 2013 resolution on the human rights of older persons, calling on states to 'promote and ensure the full realisation of all human rights and fundamental freedoms for older persons'. ${ }^{21}$ The Council appointed the first UN Independent Expert on the enjoyment of all human rights by older persons 
in 2014, with her first report calling on states to adopt a 'comprehensive, all-encompassing and human rightsbased approach to the care of older persons' through a binding international human rights instrument. ${ }^{22}$ With the COVID-19 pandemic raising awareness of the neglect, isolation and abuse of older persons, as well as the lack of adequate services (especially in long-term care facilities), OHCHR would update its Normative Standards, recognising major gaps in human rights protections that only a new legal instrument could uphold. ${ }^{23}$ As states and advocates called for a binding convention on the human rights of older persons, policymakers have looked to regional efforts in the Americas as a basis for drafting a treaty.

\section{AN INTER-AMERICAN CONVENTION}

Efforts across Latin America and the Caribbean have laid the foundation for the first regional treaty to codify comprehensively the rights of older persons. Arising out of the Second Regional Intergovernmental Conference on Ageing in Latin America and the Caribbean in 2007, the resulting Brasilia Declaration emphasised the importance of centring human rights in ageing policy, establishing a legal framework for the right to health and a monitoring mechanism to facilitate accountability. ${ }^{24}$ Where the Brasilia Declaration looked to the right to health as a basis for incorporating older persons into an inclusive society, the subsequent 2009 Declaration of Commitment of Port of Spain sought to address inequality in health services through a regional framework to promote and protect the rights of the ageing population. ${ }^{25}$ States reaffirmed their commitment to the human rights of older persons at the Third Regional Intergovernmental Conference on Ageing in Latin American and the Caribbean, with the 2012 San José Charter extending obligations to support the rights of older persons through policies that promote preventative healthcare, including through access to safe housing and education, preferential access to treatments and medicines, and prioritising the needs of older persons in emergency planning. ${ }^{26}$

The 2017 Inter-American Convention on Protecting the Human Rights of Older Persons has drawn from these regional instruments to establish special protections for older populations and facilitate supranational accountability for healthy ageing. Looking to parallel efforts by the African Union to develop the 2016 Protocol on the Rights of Older Persons ${ }^{27}$ the Organization of American States (OAS) explicitly extended the right to health to older persons, committing states under the InterAmerican Convention to 'designing and implementing intersectoral public health policies [that] promote enjoyment of the highest level of physical, mental and social well-being'. ${ }^{28}$ In recognising intersectional threats to the health and human rights of older persons, the Inter-American Convention seeks to combat all forms of discrimination and calls upon states to offer protection for vulnerable groups who may be victims of 'multiple discrimination'. While the Inter-American Convention is not yet in force, awaiting the required number of state ratifications, this legally binding instrument promises to be the first convention to codify holistically the healthrelated rights of older persons. Applying the principles of this convention in the COVID-19 response, the OAS General Assembly has explicitly acknowledged the unique vulnerabilities of older persons during the pandemic, emphasising the need to prioritise rights in all policy responses and encouraging states to ratify or accede to the convention. ${ }^{29}$

Amid an ongoing demographic transition and inequitable pandemic response, the limitations of these fragmented advancements across UN bodies, regional governance and national laws have highlighted the need for explicit international legal obligations to advance the health-related human rights of older persons. The prospective UN Convention on the Rights of Older Persons provides a crucial opportunity to elaborate comprehensively the health and human rights of older persons, establishing legal authorities to prevent discrimination and facilitate healthy ageing, intersectional approaches to the health and dignity of older persons, and accountability mechanisms to facilitate monitoring and review.

\section{POLICYMAKING PROCESSES}

Recognising a political imperative in the context of the COVID-19 pandemic to draft a Convention on the Rights of Older Persons, wide-ranging diplomatic efforts have advanced across international forums to shape this prospective convention. With the UN Secretary General publishing a May 2020 policy brief on the impact of COVID-19 on older persons, ${ }^{30}$ the UN High Commissioner for Human Rights followed by recognising how 'the lack of a dedicated normative instrument' and 'the conceptual limitations of existing instruments continue to hinder the effective protection of human rights of older persons'. ${ }^{31}$ The OEWG has continued to study normative limitations across different thematic areasranging from equality and non-discrimination to social protection, access to justice and palliative care-with each OEWG session further revealing the inter-relatedness of human rights in upholding the health of older persons. The OHCHR recognised at the March 2021 OEWG meeting that 'the silence, neglect and relative invisibility of human rights issues of central concern to older persons are widespread and systemic in the international human rights system', concluding that 'a new dedicated normative instrument is needed to comprehensively remedy those deficiencies'. ${ }^{23}$ With human rights advocates critiquing the limited progress of the OEWG in considering the elements of this proposed instrument, ${ }^{32}$ the UN Human Rights Council passed an October 2021 resolution requesting that $\mathrm{OHCHR}$ deliver recommendations to address gaps across international human rights law with regard to older persons. ${ }^{33}$ 


\section{SUBSTANTIVE AUTHORITIES}

Health and human rights threats faced by older persons in the COVID-19 pandemic have exposed limitations of existing human rights instruments, with past international and regional efforts pointing to necessary healthrelated obligations under this prospective convention. It is crucial in the convention that the right to health be expanded to provide specific obligations that respect the inherent dignity of older persons, protect against health discrimination on the basis of age and fulfil the need for age-appropriate care. Consistent with attributes of the right to health, the care provided-in the community and in long-term care facilities-must be available, accessible, acceptable, affordable and of sufficient quality, considering the needs of older populations, the advancements of medical science and the provision of palliative care. ${ }^{34}$ With specific attention to residential care settings, it will be necessary to ensure that healthcare is provided voluntarily, free of violence and undertaken with informed consent, respecting the independence, autonomy and liberty of older persons.

Beyond specific provisions of the right to health, it will be crucial that states mainstream health throughout the prospective convention, encompassing a wide range of human rights that underlie public health and proscribing prejudices that marginalise older persons. This will require an intersectional approach to the health challenges facing older persons-whether on account of income, gender, sexual orientation, race, disability or indigenous status-with efforts to ensure that health workers are trained and equipped to address overlapping vulnerabilities in realising underlying determinants of health without discrimination. ${ }^{35}$ Finally, the COVID-19 pandemic has highlighted the importance of safeguarding the rights of older persons in emergency contexts, requiring treaty provisions to ensure that older persons are prioritised in state interventions to ensure health and safety during armed conflict, natural disasters, climate change, pandemic threats, migration and other situations of risk - aligning human rights law with international humanitarian law in upholding the human rights of older persons.

\section{ACCOUNTABILITY MECHANISMS}

To facilitate accountability for these health-related human rights, monitoring and review mechanisms can uphold the rights of older persons, assessing rights realisation and encouraging national reforms. The development of a UN Convention on the Rights of Older Persons would lead to the establishment of a corresponding UN Committee on the Rights of Older Persons, responsible for interpreting treaty provisions and monitoring treaty implementation. ${ }^{36}$ Composed of independent experts specialising in the rights of older persons, this treaty body would employ robust monitoring and review processes to deter violations and encourage implementation, galvanising policy reforms, programmatic initiatives and individual remedies. ${ }^{37}$ This treaty monitoring processthrough the review of state reports, constructive dialogue with states parties and concluding observations on state implementation-would be uniquely positioned to influence state perceptions on the rights of older persons and apply external pressure to shift national practice. ${ }^{38}$ These international monitoring and review mechanisms can thus facilitate accountability for the implementation of health-related human rights, compelling states to report on the progressive realisation of treaty obligations and engaging with non-governmental advocates through the submission of 'shadow reports'. ${ }^{39}$ Such mechanisms have been seen to influence state implementation of international human rights norms, shifting domestic perceptions of human rights, ${ }^{40}$ and a Committee on the Rights of Older Persons would provide an institutional mechanism to translate the rights of older persons from political aspiration to legal reality.

\section{CONCLUSION}

The COVID-19 pandemic has laid bare the indignities faced by older persons, exposing vast inequities in health and human rights and catalysing a growing movement for a Convention on the Rights of Older Persons. This convention, extending international efforts to protect older populations through distinct legal obligations, presents crucial opportunities to support healthy ageing policy as a human rights imperative.

Twitter Benjamin Mason Meier @BenjaminMMeier, Victoria Matus @matus_tori and Maximillian Seunik @maxseunik

Contributors BMM conceptualised this study. All authors contributed equally to the research and development of the manuscript.

Funding The authors have not declared a specific grant for this research from any funding agency in the public, commercial or not-for-profit sectors.

Competing interests None declared.

Patient consent for publication Not required.

Provenance and peer review Not commissioned; externally peer reviewed.

Data availability statement No data are available.

Open access This is an open access article distributed in accordance with the Creative Commons Attribution Non Commercial (CC BY-NC 4.0) license, which permits others to distribute, remix, adapt, build upon this work non-commercially, and license their derivative works on different terms, provided the original work is properly cited, appropriate credit is given, any changes made indicated, and the use is non-commercial. See: http://creativecommons.org/licenses/by-nc/4.0/.

Author note This article is dedicated to the memories of Lola Swicar Lewin and Regina Swicar Herschtal, who survived the terrors of the Holocaust, started new families in the refugee camps, rebuilt their lives in a distant land, but were lost amid the failures of the COVID-19 response. May their memories be a blessing.

\section{ORCID iD}

Benjamin Mason Meier http://orcid.org/0000-0002-9870-1387

\section{REFERENCES}

1 Sekalala S, Forman L, Habibi R, et al. Health and human rights are inextricably linked in the COVID-19 response. BMJ Glob Health 2020;5:e003359.

2 Hrynick TA, Ripoll Lorenzo S, Carter SE. COVID-19 response: mitigating negative impacts on other areas of health. BMJ Glob Health 2021;6:e004110. 
3 World Health Organization. Preventing and managing COVID-19 across long-term care services: policy brief, 2020. Available: https:// apps.who.int/iris/handle/10665/333074

4 MacAskill A. UK PM Johnson dismissed COVID-19 lockdown as only elderly would die, ex-aide says, 2021. Available: https://www.reuters. $\mathrm{com} /$ world/uk/uk-pm-johnson-dismissed-covid-19-lockdown-onlyelderly-would-die-ex-aide-says-2021-07-19/

5 'Cada família que cuide dos seus idosos', diz Bolsonaro sobre flexibilizar isolamento, 2020. Available: https://catracalivre.com.br/ cidadania/cada-familia-que-cuide-dos-seus-idosos-diz-bolsonarosobre-flexibilizar-isolamento/

6 Lloyd-Sherlock P, Lasco G, McKee M, et al. Does vaccine ageism amount to gerontocide? Lancet 2021;398:952-3.

7 Fraser S, Lagacé M, Bongué B, et al. Ageism and COVID-19: what does our society's response say about us? Age Ageing 2020;49:692-5.

8 National Academies of Sciences, Engineering, and Medicine. Social isolation and loneliness in older adults: opportunities for the health care system. Washington, DC: National Academies Press, 2020.

9 World Health Organization. Leaders speak out about their concerns regarding older people in the context of COVID-19, 2020. Available: https://www.who.int/news-room/feature-stories/detail/leadersspeak-out-older-people-covid-19

10 Office of the High Commissioner for Human Rights. COVID-19 guidance, 2020. Available: https://www.ohchr.org/Documents/ Events/COVID-19 Guidance.pdf

11 United Nations General Assembly. Declaration of Old Age Rights. A RES/213(III) 1948

12 United Nations,. Universal Declaration of human rights 1948.

13 United Nations,. Report of the world assembly on aging, A/ CONF.113/31 1982

14 United Nations General Assembly. Principles of older persons, Res 46//91 1991

15 Office of the High Commissioner for Human Rights. CESCR General Comment No. 6: social and cultural rights of older persons, E/1996/22 1996.

16 United Nations,. Political Declaration and Madrid international plan of action on ageing 2002.

17 United Nations General Assembly,. Open-Ended Working group on ageing for the purpose of strengthening the protection of the human rights of older persons, Res 65/182 2011.

18 United Nations Human Rights Council,. Thematic study on the realization of the right to health of older persons by the special Rapporteur on the right of everyone to the enjoyment of the highest attainable standard of physical and mental health, $\mathrm{A} / \mathrm{HRC} / 18 / 37$ 2011

19 United Nations General Assembly,. Open-Ended Working group on ageing for the purpose of strengthening the protection of the human rights of older persons, Res 65/182 2013.

20 Office of the High Commissioner for Human Rights. Normative standards in international human rights law in relation to older persons 2012.

21 United Nations Human Rights Council,. The human rights of older persons, A/HRC/RES/24/20 2013.

22 United Nations Human Rights Council,. Report of the independent expert on the enjoyment of all human rights by older persons, $\mathrm{A}$ HRC/33/44 2016.
23 Office of the High Commissioner for Human Rights. Update to the 2012 analytical outcome study on the normative standards in international human rights 2021

24 United Nations Economic Commission for Latin America and the Caribbean,. Brasilia Declaration 2007.

25 Organization of American States,. Declaration of commitment of port of Spain, GRIC/OP.3/doc.4/09 2009.

26 United Nations Economic Commission for Latin America and the Caribbean,. San Jose charter on the rights of older persons in Latin American and the Caribbean, LC/G.2537 2012.

27 Chirwa DM, Rushwaya Cl. Guarding the guardians: a critical appraisal of the protocol to the African charter on the rights of older persons in Africa. Human Rights Law Review 2019;19:53-82.

28 Organization of American States,. Inter-American convention on protecting the human rights of older persons 2017.

29 Organization of American States,. Promotion and protection of human rights, AG/RES. 29612020

30 United Nations. Policy brief: the impact of COVID-19 on older persons, 2020. Available: https://unsdg.un.org/sites/default/files/ 2020-05/Policy-Brief-The-Impact-of-COVID-19-on-Older-Persons. pdf

31 Bachelet M. Message from Michelle Bachelet, United nations high commissioner for human rights. Presented at: 11th session of the open-ended Working group on ageing 2021.

32 The Global Alliance for the Rights of Older People. An open letter to the United Nations general assembly's open-ended working group on ageing for the purpose of strengthening the protection of the human rights of older persons, 2021. Available: https:// rightsofolderpeople.org/wp-content/uploads/2021/09/Open-Letterfor-OEWGA-Bureau_20-Sep-2021_signatories.pdf

33 United Nations Human Rights Council,. Human rights of older persons, A/HRC/RES/48/3 2021.

34 Office of the High Commissioner for Human Rights. CESCR General Comment No. 14: the right to the highest attainable standard of health, E/C.12/200/4 2000.

35 Williams C, Bennett E, Meier BM. Incorporating a gender perspective to realise the health and human rights of older persons. In: Taylor AL, Kuszler P, eds. Ageing, health and international law: towards an international legal framework to advance the health and human rights of older persons. Cheltenham: Elgar, 2022.

36 Meier BM, Gomes B V. Human rights treaty bodies: monitoring, interpreting, and adjudicating health-related human rights. In: Meier BM, Gostin LO, eds. Human rights in global health: rights-based governance for a globalizing world. New York: Oxford University Press, 2018: 509-31.

37 Hafner-Burton EM. Sticks and stones: naming and shaming the human rights enforcement problem. Int Organ 2008;62:689-716.

38 Simmons BA. Mobilizing for human rights: international law in domestic politics. Cambridge: Cambridge University Press, 2009.

39 Meier BM, Huffstetler H, Bueno de Mesquita J. Monitoring and review to assess human rights implementation. In: Gostin LO, Meier BM, eds. Foundations of global health \& human rights. New York: Oxford University Press, 2020: 155-73.

40 Simmons BA. From ratification to compliance: quantitative evidence on the spiral model. In: Risse T, Ropp SC, Sikkink K, eds. Persistent power of human rights: from commitment to compliance. Cambridge: Cambridge University Press, 2013: 43-59. 